\title{
The Effect of Different Packaging Systems on the Shelf Life of Refrigerated Ground Beef
}

\author{
Carlos A. Conte-Junior $1,2,3,4, * \mathbb{C}$, Maria Lúcia G. Monteiro ${ }^{1,2,3}$, Renata Patrícia ${ }^{3}$, \\ Eliane T. Mársico ${ }^{3}$, Márcia M. Lopes ${ }^{3}$, Thiago S. Alvares ${ }^{5(1)}$ and Sérgio B. Mano ${ }^{3}$ (i) \\ 1 Instituto de Química, Universidade Federal do Rio de Janeiro (UFRJ), Rio de Janeiro 21941-909, Brazil; \\ marialuciaguerra@yahoo.com.br \\ 2 Núcleo de Análise de Alimentos (NAL-LADETEC), Universidade Federal do Rio de Janeiro (UFRJ), \\ Rio de Janeiro 21941-598, Brazil \\ 3 Departamento de Tecnologia de Alimentos, Universidade Federal Fluminense (UFF), Niterói, \\ Rio de Janeiro 24220-000, Brazil; ceicao_5@yahoo.com.br (R.P.); elimarsico@gmail.com (E.T.M.); \\ marcia.vet@globo.com (M.M.L.); mtasbm@vm.uff.br (S.B.M.) \\ 4 Instituto Nacional de Controle de Qualidade em Saúde, Fundação Oswaldo Cruz (FIOCRUZ), \\ Rio de Janeiro 21040-900, Brazil \\ 5 Instituto de Nutrição, Universidade Federal do Rio de Janeiro (UFRJ), Rio de Janeiro 27979-000, Brazil; \\ alvares@macae.ufrj.br \\ * Correspondence: conte@iq.ufrj.br; Tel.: +55-21-3938-7825
}

Received: 11 March 2020; Accepted: 8 April 2020; Published: 14 April 2020

\begin{abstract}
The aim of this study was to investigate the effects of different packaging systems on the shelf life of refrigerated ground beef. The ground beef samples were packaged as follows: AA (100\% ambient air), $90 \mathrm{O}_{2}: 10 \mathrm{CO}_{2}\left(90 \% \mathrm{O}_{2}\right.$ and $\left.10 \% \mathrm{CO}_{2}\right), 80 \mathrm{O}_{2}: 20 \mathrm{CO}_{2}\left(80 \% \mathrm{O}_{2}\right.$ and $\left.20 \% \mathrm{CO}_{2}\right), 70 \mathrm{O}_{2}: 30 \mathrm{CO}_{2}$ $\left(70 \% \mathrm{O}_{2}\right.$ and $\left.30 \% \mathrm{CO}_{2}\right), 60 \mathrm{O}_{2}: 40 \mathrm{CO}_{2}\left(60 \% \mathrm{O}_{2}\right.$ and $\left.40 \% \mathrm{CO}_{2}\right), 50 \mathrm{O}_{2}: 50 \mathrm{CO}_{2}\left(50 \% \mathrm{O}_{2}\right.$ and $\left.50 \% \mathrm{CO}_{2}\right)$, $100 \mathrm{O}_{2}\left(100 \% \mathrm{O}_{2}\right)$, and VP (vacuum packaging). All treatments were analyzed daily for $\mathrm{O}_{2}$ and $\mathrm{CO}_{2}$ levels, $\mathrm{pH}$, filtration time, total volatile basic nitrogen (TVB-N), aerobic mesophilic heterotrophic bacteria (AMHB), and aerobic psychrotrophic heterotrophic bacteria (APHB) over 20 days at $2{ }^{\circ} \mathrm{C}$. All MAP systems had a decrease of $\mathrm{O}_{2}$ and an increase of $\mathrm{CO}_{2}$ levels during storage period $(p<0.05)$. Overall, the MAP systems were similarly able to decrease the $\mathrm{pH}$ and retard the increase of TVB-N and filtration time over the storage period $(p>0.05)$. Moreover, the MAP systems increased the lag phase and/or the generation time of both $\mathrm{AMHB}$ and $\mathrm{APHB}$, extending the shelf life by $3\left(90 \mathrm{O}_{2}: 10 \mathrm{CO}_{2}\right)$, $4\left(70 \mathrm{O}_{2}: 30 \mathrm{CO}_{2}\right.$ and $\left.100 \mathrm{O}_{2}\right)$, and 5 days $\left(80 \mathrm{O}_{2}: 20 \mathrm{CO}_{2}, 60 \mathrm{O}_{2}: 40 \mathrm{CO}_{2}, 50 \mathrm{O}_{2}: 50 \mathrm{CO}_{2}\right.$, and VP). All MAP systems were equally effective in retarding physicochemical degradation; however, $80 \mathrm{O}_{2}: 20 \mathrm{CO}_{2}$, $60 \mathrm{O}_{2}: 40 \mathrm{CO}_{2}, 50 \mathrm{O}_{2}: 50 \mathrm{CO}_{2}$, and VP were the most effective in impairing bacterial growth and extending the shelf life of ground beef stored under refrigeration.
\end{abstract}

Keywords: minced meat; modified atmosphere packaging; MAP; vacuum packaging; physicochemical quality indicators; predictive microbiology

\section{Introduction}

Brazil is one of the main world beef producers; therefore, it has been investing in alternative technological strategies to produce high-quality beef products and meet consumers' requirements [1]. Beef products, mainly ground beef, are considered ideal substrates for spoilage and pathogenic bacteria growth, resulting in a rapid loss of quality and limited shelf life [2]. This fact, together with an increased demand for the use of nonthermal processing technologies as an alternative for preserving the meat's original quality, makes it necessary to find new technological approaches for ground beef preservation [3,4]. Brazilian beef cuts are commonly displayed in vacuum packages in retail displays [1]. 
However, the color of vacuum-packed meat (dark purplish red) is unpleasant to consumers. In this way, modified atmosphere packaging (MAP) is an interesting alternative for the meat industry due to its capacity to extend shelf life and maintain the original quality parameters of fresh beef cuts until consumption [5,6]. Nonetheless, in Brazil, there is still limited information related to the application and effectiveness of MAP for some beef products. The main gases used for the MAP of fresh beef are carbon dioxide $\left(\mathrm{CO}_{2}\right)$, oxygen $\left(\mathrm{O}_{2}\right)$, and nitrogen $\left(\mathrm{N}_{2}\right)$. MAP with high levels of $\mathrm{O}_{2}(70-80 \%)$ and level of $\mathrm{CO}_{2}$ between $20-30 \%$ are widely used due to their effectiveness in reducing microbial growth and maintaining the red meat color desired by global consumers [1]. However, MAP with high levels of $\mathrm{O}_{2}$ may accelerate lipid oxidation, leading to the formation of undesirable off-flavor compounds [7], as well as protein oxidation, causing adverse effects on the tenderness and juiciness of beef products $[8,9]$.

Some authors have evaluated the influence of different concentrations of $\mathrm{CO}_{2}$ and $\mathrm{O}_{2}$ on the quality parameters of fresh beef, including minced meat, which is more perishable due to its grinding process [10-14]. It is worth highlighting that every meat cut has its own intrinsic chemical characteristics and normal microbiota, which are explicitly influenced when gas mixtures are used. Furthermore, due to microbial metabolism and the partial pressure and solubility of gases under different $\mathrm{CO}_{2}$ and $\mathrm{O}_{2}$ ratios [15,16], each product has an optimal gas composition, which is a key factor and major challenge for the successful application of MAP. However, at the present moment, there are no studies evaluating the effect of MAP over a wide range of gas compositions in ground beef from the Serratus ventralis thoracis muscle, which is used commonly to make ground beef in Brazil.

In this context, the aim of this study was to investigate the effects of different packaging systems, such as air ambient, vacuum packaging, and six different types of $\mathrm{O}_{2} / \mathrm{CO}_{2}$ blend-MAPs, on the shelf life of fresh ground beef kept under refrigerated conditions $\left(2^{\circ} \mathrm{C}\right)$ for 20 days.

\section{Materials and Methods}

\subsection{Beef Sampling}

Nellore (Bos indicus) bulls were slaughtered in a local federal inspected abattoir (São João de Meriti, Rio de Janeiro, Brazil). The carcasses were maintained cool at $0{ }^{\circ} \mathrm{C}$. Serratus ventralis thoracis (SVT) muscles were sampled $24 \mathrm{~h}$ post-mortem from the left halves of the carcasses, deboned manually at $12{ }^{\circ} \mathrm{C}$, and the excess fat, aponeuroses, ligaments, tendons, and lymph nodes were removed. The SVT muscles were then cut into steaks, vacuum-packed, and conveyed to the grinding section in an air-conditioned environment at $5{ }^{\circ} \mathrm{C}$.

\subsection{Preparation of Ground Beef}

Steaks cut were ground using a large-scale stainless steel meat grinder (AFMG300, Hess Meat Machines, St. Louis, MO, USA) equipped with a $13 \mathrm{~mm}$ mesh filter plate and a working capacity up to $9000 \mathrm{~kg} / \mathrm{h}$. The obtained ground beef was then conveyed to the mixer (DMX300, Hess Meat Machines, USA) equipped with one paddle. During mixing, dry ice was injected into the ground beef through jets mounted at the bottom of the mixer. The temperature of the ground beef at the mixer outlet was reduced to around $-0.7^{\circ} \mathrm{C}$.

For further mincing, the ground beef was ground through a second stainless steel meat grinder (AFMG50, Hess Meat Machines, USA) equipped with a $3.2 \mathrm{~mm}$ mesh filter plate with a working capacity up to $1800 \mathrm{~kg} / \mathrm{h}$. The resulting ground beef at the grinder output was divided into equal portions of $0.8 \mathrm{~kg}$ using an electronic balance (AW6200GP, Hess Meat Machines, USA) and conveyed for packaging.

\subsection{Packaging and Storage of Ground Beef}

Ground beef samples were packed into heat-shrink Cryovac ${ }^{\circledR}$-BB4L bags, composed principally of polyolefine and polyvinylidene chloride layers, with a thickness of $102 \mu \mathrm{m}$ and gas permeability 
(at $25^{\circ} \mathrm{C}$ ) of $62.5 \mathrm{~cm}^{3} / \mathrm{h} / \mathrm{m} / \mathrm{MPa}$ for $\mathrm{CO}_{2}, 14.6 \mathrm{~cm}^{3} / \mathrm{h} / \mathrm{m} / \mathrm{MPa}$ for $\mathrm{O}_{2}$, and $0.6 \mathrm{~cm}^{3} / \mathrm{h} / \mathrm{m} / \mathrm{MPa}$ for $\mathrm{N}_{2}$, as provided by the manufacturer. A heat-shrink pack sealer (model Sipromac Vac 300, Hess Meat Machines, USA) equipped with a vacuum chamber was used for the packaging and injection of gases that were mixed and certified by a WITT-Gasetechnik device (WITT-Gasetechnik GmbH and Co $\mathrm{KG}$, Witten, Germany). The gases $\mathrm{O}_{2}$ and $\mathrm{CO}_{2}$ were supplied from Linde AGA (Lohne, Germany). The ground beef samples were packaged as follows: AA (100\% ambient air), $90 \mathrm{O}_{2}: 10 \mathrm{CO}_{2}\left(90 \% \mathrm{O}_{2}\right.$ and $\left.10 \% \mathrm{CO}_{2}\right), 80 \mathrm{O}_{2}: 20 \mathrm{CO}_{2}\left(80 \% \mathrm{O}_{2}\right.$ and $\left.20 \% \mathrm{CO}_{2}\right), 70 \mathrm{O}_{2}: 30 \mathrm{CO}_{2}\left(70 \% \mathrm{O}_{2}\right.$ and $\left.30 \% \mathrm{CO}_{2}\right), 60 \mathrm{O}_{2}: 40 \mathrm{CO}_{2}$ $\left(60 \% \mathrm{O}_{2}\right.$ and $\left.40 \% \mathrm{CO}_{2}\right), 50 \mathrm{O}_{2}: 50 \mathrm{CO}_{2}\left(50 \% \mathrm{O}_{2}\right.$ and $\left.50 \% \mathrm{CO}_{2}\right), 100 \mathrm{O}_{2}\left(100 \% \mathrm{O}_{2}\right)$, and $\mathrm{VP}$ (vacuum packaging). The packed ground beef samples were then held at $2{ }^{\circ} \mathrm{C}$ in a conventional refrigerator coupled to an internal digital thermometer (TH 439, Equitherm, Rio de Janeiro, Brazil) with a scale ranging from $-10{ }^{\circ} \mathrm{C}$ to $50^{\circ} \mathrm{C}$ to monitor the temperature of the samples during all storage periods (20 days). The samples were then analyzed for $\mathrm{pH}$, filtration time, and TVB-N, AMHB, and APHB counts. The criterion for determining the days of analyses was based on obtaining the stationary phase of both bacterial groups (AMHB and APHB) for each treatment according to the predictive primary model designed by Baranyi and Roberts [17] through the DMFit program version 2.0 (Institute of Food Research, Norwich, UK). This occurred on day 9 for AA and on day 20 for all other treatments. Therefore, AA was evaluated daily from day 0 to 9 , while $90 \mathrm{O}_{2}: 10 \mathrm{CO}_{2}, 80 \mathrm{O}_{2}: 20 \mathrm{CO}_{2}, 70 \mathrm{O}_{2}: 30 \mathrm{CO}_{2}$, $60 \mathrm{O}_{2}: 40 \mathrm{CO}_{2}, 50 \mathrm{O}_{2}: 50 \mathrm{CO}_{2}, 100 \mathrm{O}_{2}$, and VP were evaluated daily from day 0 to 20 . In the experiment, $48 \mathrm{~h}$ post-mortem is day 0 . In addition, it is worth noting that ground beef is usually manufactured from beef cuts of a lower quality, such as Serratus ventralis thoracis. Nevertheless, there are no studies investigating the effects of different packaging systems, including MAP, on ground beef from this beef muscle.

\subsection{Gas Analysis}

Gas analysis of the internal atmosphere was carried out every storage day using a digital $\mathrm{O}_{2} / \mathrm{CO}_{2}$ headspace gas analyzer (OXYBABY ${ }^{\circledR}$, WITT-Gasetechnik GmbH and Co KG, Witten, Germany) by withdrawing a $10 \mathrm{~mL}$ gas sample through a septum glued onto the surface of the pack using the analyzer's needle [13].

\subsection{Physicochemical Analyses}

The $\mathrm{pH}$ values were measured through a digital pH meter (K39-1014B, Kasvi, Paraná, Brazil) by direct insertion of the electrode into the sample [18].

Total volatile basic nitrogen (TVB-N) was determined in $10 \mathrm{~g}$ of ground beef using the Conway micro-diffusion method according to the protocol established by the Association of Official Analytical Chemists [19].

The alteration of the freshness and integrity of the myofibrils was assessed using a filtration test. Ten grams of ground beef sample homogenized into $100 \mathrm{~mL}$ of distilled water were filtered using Whatman paper No. $40[20,21]$, and the results were obtained by timing the filtration time.

\subsection{Bacteriological Analyses}

The aerobic mesophilic heterotrophic bacteria (AMHB) and aerobic psychrotrophic heterotrophic bacteria (APHB) in the meat sample were analyzed using the standard methods of the American Public Health Association [22]. Samples of ground beef $(25 \mathrm{~g})$ in the stomacher bags were aseptically added to $225 \mathrm{~mL}$ of sterile buffered peptone water solution $(0.1 \% \mathrm{w} / \mathrm{v})$ and homogenized for $2 \mathrm{~min}$ at $25^{\circ} \mathrm{C}$. After successive decimal dilutions, a suitable dilution $100 \mu \mathrm{L}$ in volume was applied on the surfaces of the agar plates. AMHB and APHB were determined on a plate count agar (PCA; Difco Laboratories, Detroit, MI, USA), incubated at $35^{\circ} \mathrm{C}$ for $48 \mathrm{~h}$, and then at $7{ }^{\circ} \mathrm{C}$ for ten days. Plates enclosing from 25 to 250 colonies were chosen, and the average number of $\mathrm{cfu} / \mathrm{g}$ was calculated. Bacterial colonies were considered and expressed as Log cfu (colony forming units) per gram of ground beef. 


\subsection{Statistical Analyses}

The number of total samples analyzed was 298 , and all analyses were performed in duplicate [1 (AA treatment) $\times 9$ (days of storage) $\times 2$ (duplicate) $+7\left(90 \mathrm{O}_{2}: 10 \mathrm{CO}_{2}, 80 \mathrm{O}_{2}: 20 \mathrm{CO}_{2}, 70 \mathrm{O}_{2}: 30 \mathrm{CO}_{2}, 60 \mathrm{O}_{2}: 40 \mathrm{CO}_{2}\right.$, $50 \mathrm{O}_{2}: 50 \mathrm{CO}_{2}, 100 \mathrm{O}_{2}$ and $\mathrm{VP}$ treatments) $\times 20$ (days of storage) $\times 2$ (duplicate)]. The relationship between each $\mathrm{pH}, \mathrm{TVB}-\mathrm{N}$, filtration time, and days of storage was separately analyzed for each treatment through a linear regression analysis. A one-way ANOVA and Tukey's post hoc test was used to identify differences in the total amount of each physicochemical parameter produced during the storage period between the treatments. The bacterial growth curves were fit according to a predictive primary model using the statistical program DMFit 2.0 (Institute of Food Research, Norwich, UK) designed by Baranyi and Roberts [17]. This program was also used to obtain the bacterial growth parameters (lag phase-Lag, generation time-GT, and number of colonies in the stationary phase-NC) of each treatment, which were further evaluated by a one-way ANOVA with a Tukey post-hoc test. All analyses were performed using the XLSTAT software, version 2012.6.08 (Addinsoft, New York, NY, USA), at a 0.05 level of confidence $(p<0.05)$.

\section{Results and Discussion}

\subsection{Headspace Gas Levels in the MAP Samples}

A significant reduction of $\mathrm{O}_{2}$ and an increase in $\mathrm{CO}_{2}$ levels $(p<0.05)$ were observed for all the MAP types (Figure 1). This behavior could be related to the dominant bacteria in the refrigerated meat packed with MAP [23]. While Pseudomonas sp. utilize available oxygen in the headspace, facultative anaerobic lactic acid bacteria, such as Brochothrix thermosphacta, and lactic acid bacteria (LAB) produce carbon dioxide as a metabolic product, causing a reduction of $\mathrm{O}_{2}$ and the emission of $\mathrm{CO}_{2}$ into packages during the storage period $[13,23,24]$. Similarly, the emission of $\mathrm{CO}_{2}$ and consumption of $\mathrm{O}_{2}$ were also observed in previous studies [13,25-27].

Regarding the rate of $\mathrm{O}_{2}$ reduction, the plots of $\mathrm{O}_{2}$ and $\mathrm{CO}_{2}$ levels crossed over approximately at the same storage time (13-14 days), despite their different initial $\mathrm{O}_{2}$ and $\mathrm{CO}_{2}$ levels. The intersections of the $\mathrm{O}_{2}$ and $\mathrm{CO}_{2}$ plots had approximately the same $\mathrm{O}_{2}$ and $\mathrm{CO}_{2}$ levels, ranging from $46 \%$ to $50 \%(v / v)$. The barrier property of the packaging material is likely the reason for this behavior. Indeed, the oxygen permeability of the Cryovac ${ }^{\circledR}$-BB4L bag depends on the differential partial pressure of $\mathrm{O}_{2}$ between the internal and external sides of the packaging material. After a certain time, gas composition in the package of the ground beef reaches a definite balance between the respiration rate and permeability of the packaging material. In this state of equilibrium, the total amounts of $\mathrm{CO}_{2}$ emitted and $\mathrm{O}_{2}$ consumed by respiration are the same as those permeated through the packaging material exchange [28]. The respiration of ground beef, storage environmental factors (i.e., temperature and relative humidity), and the permeability of the packing materials determine the gas composition at this equilibrium state after a storage time of $13-14$ days $[13,28]$. 
$90 \mathrm{O}_{2}: 10 \mathrm{CO}_{2}$

$80 \mathrm{O}_{2}: 20 \mathrm{CO}_{2}$
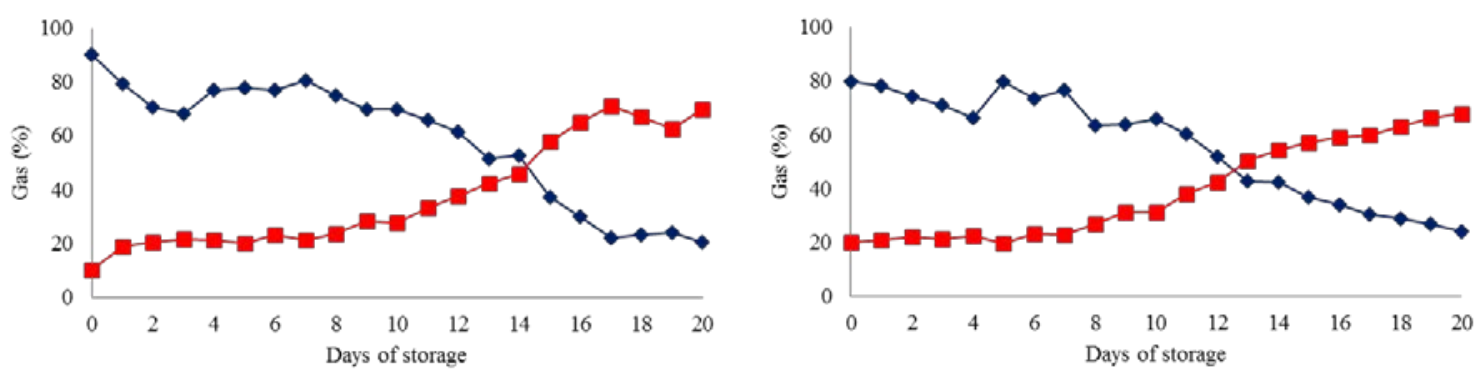

$70 \mathrm{O}_{2}: 30 \mathrm{CO}_{2}$
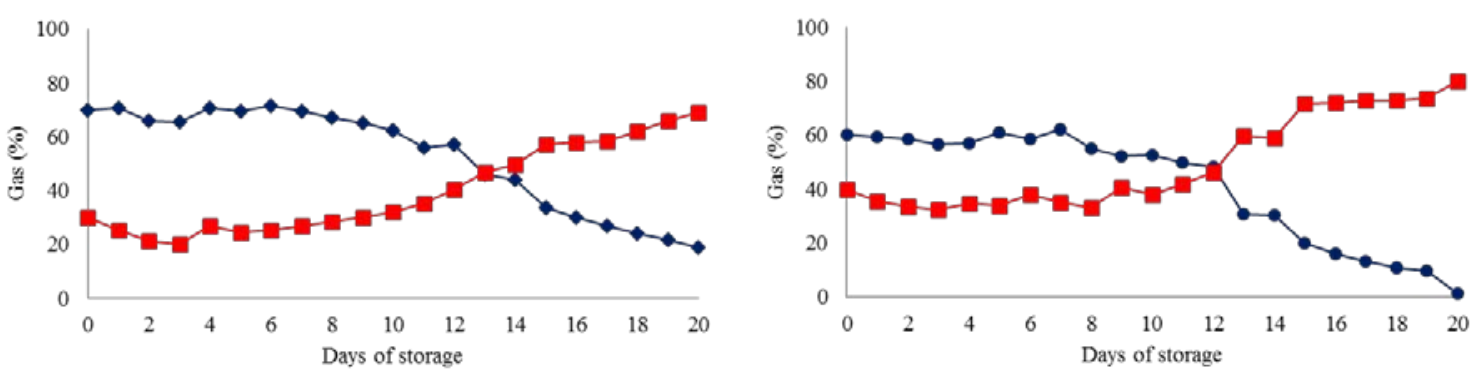

$50 \mathrm{O}_{2}: 50 \mathrm{CO}_{2}$

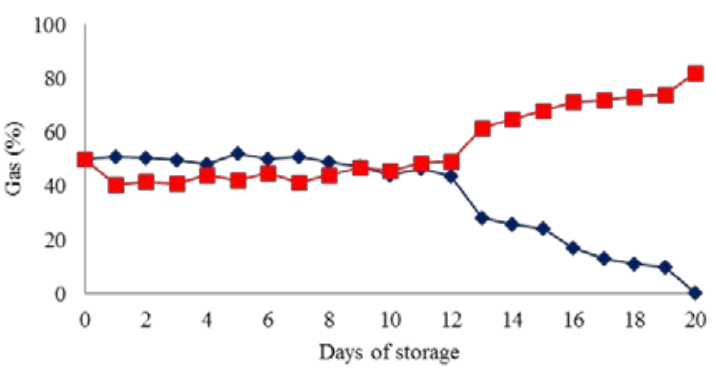

$100 \mathrm{O}_{2}$

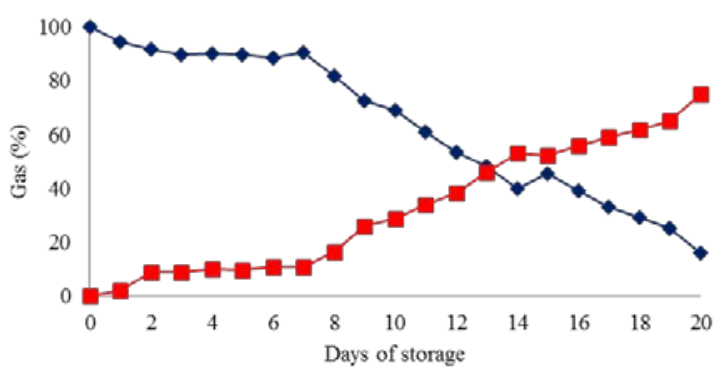

Figure 1. Effect of storage time on the headspace $\mathrm{O}_{2}$ (blue color) and $\mathrm{CO}_{2}$ levels (red color) of ground beef treated with different packaging systems stored at $2{ }^{\circ} \mathrm{C}$ for 20 days. $90 \mathrm{O}_{2}: 10 \mathrm{CO}_{2}, 80 \mathrm{O}_{2}: 20 \mathrm{CO}_{2}$, $70 \mathrm{O}_{2}: 30 \mathrm{CO}_{2}, 60 \mathrm{O}_{2}: 40 \mathrm{CO}_{2}, 50 \mathrm{O}_{2}: 50 \mathrm{CO}_{2}$, and $100 \mathrm{O}_{2}$ (modified atmosphere packaging with $90 \%: 10 \%$, 80\%:20\%, 70\%:30\%, 60\%:40\%, 50\%:50\%, and 100\%:0\% oxygen and dioxide carbon ratios, respectively).

\subsection{Physicochemical Parameters}

During the entire period of storage, AA showed an increase, while the other treatments demonstrated a decrease in $\mathrm{pH}$ values $(p<0.05$; Table 1$)$. AA had the highest $\mathrm{pH}$ value $(p<0.05)$, and no difference $(p>0.05)$ was observed among the remaining treatments until the 9 th day of storage. Amongst packaging system treatments from the 10 th to 20th day of storage, $100 \mathrm{O}_{2}$ had a higher $\mathrm{pH}$ value than VP, $60 \mathrm{O}_{2}: 40 \mathrm{CO}_{2}$, and $50 \mathrm{O}_{2}: 50 \mathrm{CO}_{2}(p<0.05)$, and VP showed the lowest value for this parameter $(p<0.05)$, except when compared to $50 \mathrm{O}_{2}: 50 \mathrm{CO}_{2}(p>0.05$; Table 1$)$. 
Table 1. Physicochemical parameters of the ground beef treated with different packaging systems stored at $2{ }^{\circ} \mathrm{C}$ for 20 days.

\begin{tabular}{|c|c|c|c|c|c|c|c|}
\hline \multirow{2}{*}{ Parameters } & \multirow{2}{*}{ Treatments $€$} & \multicolumn{2}{|c|}{$\Delta_{0-20}{ }^{£}$} & \multicolumn{4}{|c|}{ Linear Regression Coefficients } \\
\hline & & $\Delta_{0-9}$ & $\Delta_{10-20}$ & $y$-Intercept & Slope & $p$-Value & $r$-Squared \\
\hline \multirow{8}{*}{$\mathrm{pH}$} & AA & $6.15 \pm 0.28^{a}$ & NA & $5.85 \pm 0.13$ & $0.07 \pm 0.02$ & 0.0230 & 0.496 \\
\hline & $90 \mathrm{O}_{2}: 10 \mathrm{CO}_{2}$ & $5.95 \pm 0.08^{b}$ & $5.83 \pm 0.06^{\mathrm{a}, \mathrm{b}}$ & $6.01 \pm 0.02$ & $-0.01 \pm 0.00$ & $<0.0001$ & 0.644 \\
\hline & $80 \mathrm{O}_{2}: 20 \mathrm{CO}_{2}$ & $5.94 \pm 0.08^{b}$ & $5.84 \pm 0.05^{\mathrm{a}, \mathrm{b}}$ & $5.99 \pm 0.02$ & $-0.01 \pm 0.00$ & 0.0000 & 0.596 \\
\hline & $70 \mathrm{O}_{2}: 30 \mathrm{CO}_{2}$ & $5.95 \pm 0.06^{b}$ & $5.81 \pm 0.08^{a, b}$ & $6.01 \pm 0.02$ & $-0.01 \pm 0.00$ & $<0.0001$ & 0.715 \\
\hline & $60 \mathrm{O}_{2}: 40 \mathrm{CO}_{2}$ & $5.94 \pm 0.09^{b}$ & $5.77 \pm 0.08^{b}$ & $6.01 \pm 0.03$ & $-0.02 \pm 0.00$ & $<0.0001$ & 0.650 \\
\hline & $50 \mathrm{O}_{2}: 50 \mathrm{CO}_{2}$ & $5.94 \pm 0.06^{b}$ & $5.73 \pm 0.10^{b, c}$ & $6.01 \pm 0.03$ & $-0.02 \pm 0.00$ & $<0.0001$ & 0.779 \\
\hline & $100 \mathrm{O}_{2}$ & $5.93 \pm 0.11^{b}$ & $5.90 \pm 0.10^{\mathrm{a}}$ & $5.99 \pm 0.04$ & $-0.01 \pm 0.00$ & 0.0420 & 0.204 \\
\hline & $\mathrm{VP}$ & $5.86 \pm 0.17^{b}$ & $5.63 \pm 0.07^{c}$ & $5.94 \pm 0.05$ & $-0.02 \pm 0.00$ & 0.0000 & 0.531 \\
\hline \multirow{8}{*}{ TVB-N $¥$} & AA & $18.64 \pm 11.39^{a}$ & NA & $5.82 \pm 4.63$ & $2.85 \pm 0.87$ & 0.0110 & 0.574 \\
\hline & $90 \mathrm{O}_{2}: 10 \mathrm{CO}_{2}$ & $11.45 \pm 1.98^{b}$ & $16.26 \pm 4.58^{a}$ & $8.45 \pm 1.03$ & $0.57 \pm 0.09$ & $<0.0001$ & 0.685 \\
\hline & $80 \mathrm{O}_{2}: 20 \mathrm{CO}_{2}$ & $11.79 \pm 1.37^{\mathrm{b}}$ & $16.06 \pm 4.00^{\mathrm{a}}$ & $9.17 \pm 0.85$ & $0.50 \pm 0.08$ & $<0.0001$ & 0.713 \\
\hline & $70 \mathrm{O}_{2}: 30 \mathrm{CO}_{2}$ & $11.63 \pm 1.21^{b}$ & $14.45 \pm 4.39^{\mathrm{a}}$ & $9.29 \pm 1.04$ & $0.40 \pm 0.10$ & 0.0010 & 0.505 \\
\hline & $60 \mathrm{O}_{2}: 40 \mathrm{CO}_{2}$ & $11.50 \pm 0.94^{b}$ & $14.88 \pm 3.15^{\mathrm{a}}$ & $9.65 \pm 0.72$ & $0.35 \pm 0.07$ & $<0.0001$ & 0.629 \\
\hline & $50 \mathrm{O}_{2}: 50 \mathrm{CO}_{2}$ & $11.70 \pm 0.91^{\mathrm{b}}$ & $15.58 \pm 2.75^{\mathrm{a}}$ & $9.76 \pm 0.57$ & $0.41 \pm 0.05$ & $<0.0001$ & 0.785 \\
\hline & $100 \mathrm{O}_{2}$ & $11.52 \pm 0.88^{b}$ & $16.34 \pm 4.81^{\mathrm{a}}$ & $8.70 \pm 1.05$ & $0.55 \pm 0.10$ & $<0.0001$ & 0.662 \\
\hline & $\mathrm{VP}$ & $12.04 \pm 1.65^{b}$ & $15.39 \pm 4.11^{\mathrm{a}}$ & $9.62 \pm 0.98$ & $0.43 \pm 0.09$ & 0.0000 & 0.582 \\
\hline \multirow{8}{*}{ Filtration time ${ }^{¥}$} & AA & $33.89 \pm 27.49^{a}$ & NA & $-3.54 \pm 5.07$ & $8.22 \pm 0.93$ & $<0.0001$ & 0.918 \\
\hline & $90 \mathrm{O}_{2}: 10 \mathrm{CO}_{2}$ & $17.33 \pm 11.76^{b}$ & $42.32 \pm 16.94^{\mathrm{a}}$ & $3.90 \pm 4.43$ & $2.71 \pm 0.39$ & $<0.0001$ & 0.747 \\
\hline & $80 \mathrm{O}_{2}: 20 \mathrm{CO}_{2}$ & $17.78 \pm 12.36^{b}$ & $35.22 \pm 7.95^{\mathrm{a}, \mathrm{b}}$ & $8.87 \pm 3.45$ & $1.84 \pm 0.31$ & $<0.0001$ & 0.693 \\
\hline & $70 \mathrm{O}_{2}: 30 \mathrm{CO}_{2}$ & $18.67 \pm 13.11^{b}$ & $31.03 \pm 7.41^{\mathrm{a}, \mathrm{b}}$ & $14.02 \pm 4.60$ & $1.13 \pm 0.41$ & 0.0140 & 0.324 \\
\hline & $60 \mathrm{O}_{2}: 40 \mathrm{CO}_{2}$ & $16.89 \pm 11.67^{b}$ & $29.44 \pm 9.08^{a, b}$ & $12.55 \pm 4.59$ & $1.11 \pm 0.41$ & 0.0150 & 0.316 \\
\hline & $50 \mathrm{O}_{2}: 50 \mathrm{CO}_{2}$ & $17.22 \pm 11.94^{b}$ & $29.17 \pm 6.95^{\mathrm{a}, \mathrm{b}}$ & $12.97 \pm 4.26$ & $1.07 \pm 0.38$ & 0.0120 & 0.333 \\
\hline & $100 \mathrm{O}_{2}$ & $18.56 \pm 13.25^{b}$ & $38.07 \pm 6.51^{\mathrm{a}}$ & $9.89 \pm 3.73$ & $1.93 \pm 0.33$ & $<0.0001$ & 0.678 \\
\hline & $\mathrm{VP}$ & $17.33 \pm 11.54^{b}$ & $22.54 \pm 3.78^{b}$ & $12.55 \pm 3.40$ & $0.77 \pm 0.30$ & 0.0210 & 0.289 \\
\hline
\end{tabular}

The results are expressed as the means \pm standard deviation $(n=2)$. NA-Not applicable. ${ }^{\mathrm{a}, \mathrm{b}, \mathrm{c}}$ Different letters indicate significant differences $(p<0.05)$ between treatments. ${ }^{\epsilon}$ AA (ambient air); $90 \mathrm{O}_{2}: 10 \mathrm{CO}_{2}, 80 \mathrm{O}_{2}: 20 \mathrm{CO}_{2}, 70 \mathrm{O}_{2}: 30 \mathrm{CO}_{2}, 60 \mathrm{O}_{2}: 40 \mathrm{CO}_{2}, 50 \mathrm{O}_{2}: 50 \mathrm{CO}_{2}$, and $100 \mathrm{O}_{2}$ (modified atmosphere packaging with $90 \%: 10 \%, 80 \%: 20 \%, 70 \%: 30 \%, 60 \%: 40 \%, 50 \%: 50 \%$, and $100 \%: 0 \%$ of oxygen and dioxide carbon ratios, respectively); VP (vacuum packaging). ${ }^{¥}$ TVB-N—total volatile basic nitrogen in mg for TVB-N/100g of meat; filtration time in min. ${ }^{£}$ Values for the total amount of each physicochemical parameter during the storage period from day 0 to $9\left(\Delta_{0-9}\right)$ and from day 10 to $20\left(\Delta_{10-20}\right)$. 
Brazilian regulations declare 6.4 as the maximum tolerated $\mathrm{pH}$ of meat destined for human consumption [29]. The initial $\mathrm{pH}$ value of ground beef was 6.1 (Figure 2A). AA exceeded this limit on day 9 when it reached a $\mathrm{pH}$ value of 6.8. On the other hand, all other treatments had a $\mathrm{pH}$ ranging from about 6.10 to 5.80 and, therefore, did not achieve a $\mathrm{pH}$ value of 6.4 throughout refrigerated storage.

The increase in the $\mathrm{pH}$ value for AA might be attributed to the accumulation of basic compounds derived from the growth of Pseudomonas spp. and associated sub-species [30]. The decrease of the $\mathrm{pH}$ value in $10-50 \% \mathrm{CO}_{2}$ MAP treatments may be attributed to the formation of carbonic acid by the dissolution of $\mathrm{CO}_{2}$ in water [31]. In vacuum packaging, a decrease in $\mathrm{pH}$ values may be due to low $\mathrm{O}_{2}$ levels favoring the growth of acid lactic bacteria, which are facultative anaerobic bacteria [32,33]. Similar findings were previously reported in the literature for meat [34,35].

The TVB-N parameter is utilized as a food freshness indicator, since volatile nitrogen-based compounds are the product of the degradation of protein and non-protein nitrogen compounds, such as trimethylamine (TMA) and ammonia, which are mainly associated with the growth of spoilage bacteria [36]. Although the TVB-N values increased in all treatments during the entire storage period, this increase occurred more rapidly in AA (Table 1). AA showed the highest TVB-N values $(p<0.05)$ until the 9th day of storage, and the remaining treatments were similar for this parameter during all storage periods $(p>0.05$; Table 1$)$.

The initial TVB-N value was $10.70 \mathrm{mg}$ of TVB-N/100 $\mathrm{g}$, which is acceptable according to the standards recommended by Brazilian regulations. However, AA exhibited $49.00 \mathrm{mg}$ of TVB-N/100 $\mathrm{g}$ on the 9th day of storage, which is higher than the standard limits ( $\leq 30 \mathrm{mg}$ of TVB-N/100 g) [28]. All other treatments did not reach this limit throughout the refrigerated storage period, producing values between 18.55 and $23.98 \mathrm{mg}$ of TVB-N/100 $\mathrm{g}$ on the last day of storage (Figure 2B).

Our results revealed that both $\mathrm{O}_{2} / \mathrm{CO}_{2}$ enriched atmospheres and vacuum packaging reduced the growth of spoilage bacteria, probably due to the antibacterial activity of $\mathrm{CO}_{2}$ and the high levels or absence of $\mathrm{O}_{2}[30,33,37]$. In agreement with our findings, some authors have already reported that MAP with different $\mathrm{O}_{2}$ and $\mathrm{CO}_{2}$ ratios and vacuum packaging can delay the formation of TVB-N by decreasing the growth rate of spoilage bacteria in refrigerated meat $[36,38]$. Furthermore, the TVB-N analysis proved to be a useful indicator for monitoring the freshness of ground beef, although further analyses should be performed in order to establish reference values for ground beef using this parameter.

The filtration time increased under all treatments over the storage period. However, the filtration time was much more pronounced in AA $(p<0.05$; Table 1$)$. Until the 9 th day of storage, AA showed the highest filtration time $(p<0.05)$, and the remaining treatments were similar for this parameter $(p>0.05)$. From the 10th to 20th day of storage, VP demonstrated a lower filtration time $(p<0.05)$ than that of $90 \mathrm{O}_{2}: 10 \mathrm{CO}_{2}$ and $100 \mathrm{O}_{2}$, which did not differ from each other $(p>0.05)$. Likewise, the $20-50 \%$ $\mathrm{CO}_{2}$ MAP treatments had similar filtration times to $90 \mathrm{O}_{2}: 10 \mathrm{CO}_{2}, 100 \mathrm{O}_{2}$, and $\mathrm{VP}(p>0.05)$.

According to Brazilian regulations [20], a filtration time of $5 \mathrm{~min}$ indicates fresh meat suitable for consumption, 6-10 min indicates a meat of medium quality, and $\geq 10$ min means an altered meat that is not suitable for consumption. AA exceeded $10 \mathrm{~min}$ of filtration time on day 3 of refrigerated storage (15 min), while all other treatments exceeded this limit on day 5 (22-32 min; Figure 2C). On the 9th day of storage, AA showed $72 \mathrm{~min}$ of filtration time, and the remaining treatments had filtration times ranging from 23 to 38 (Figure $2 \mathrm{C}$ ). 

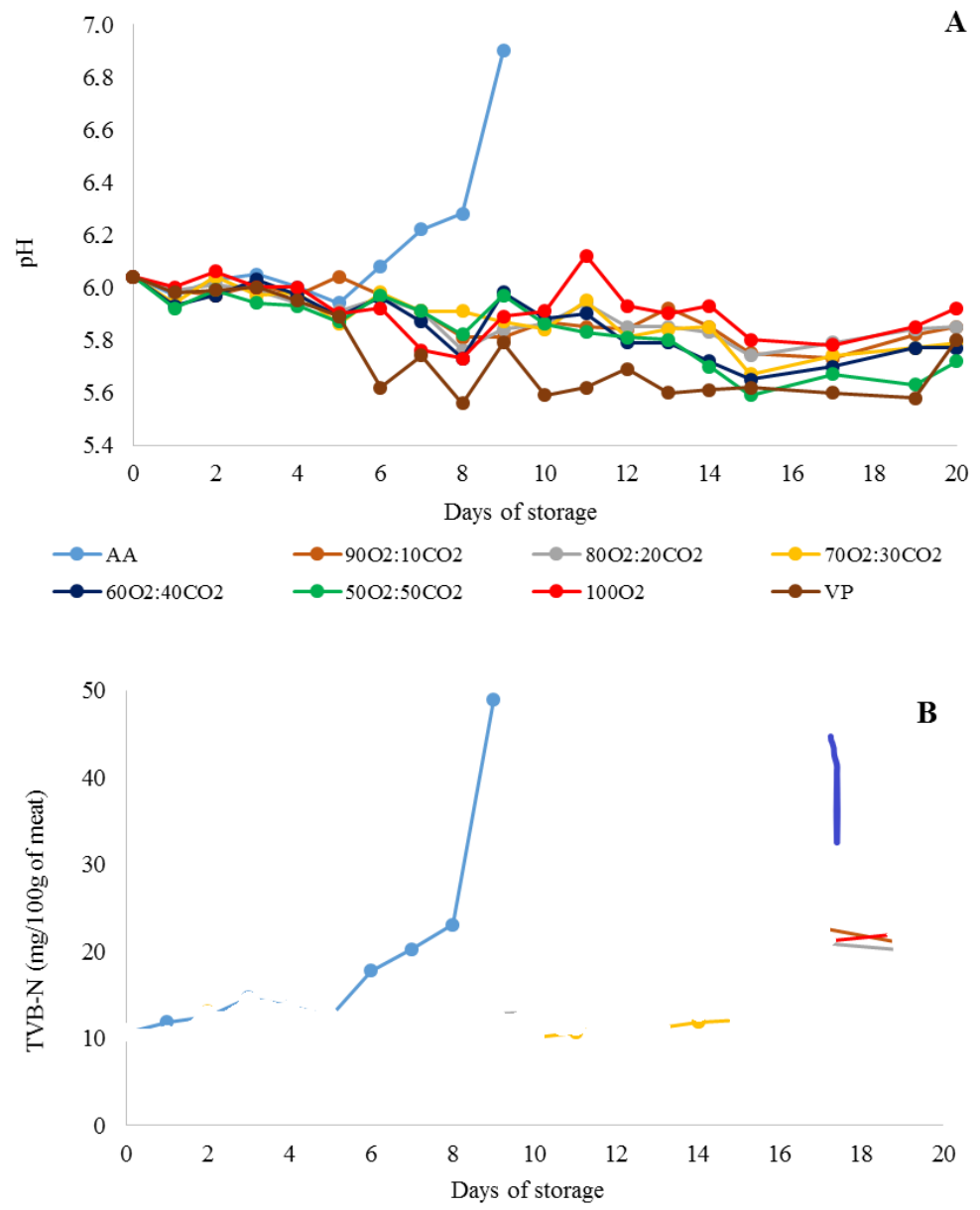

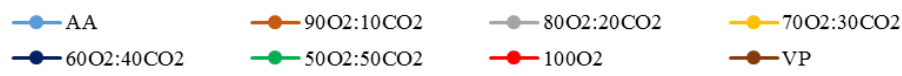

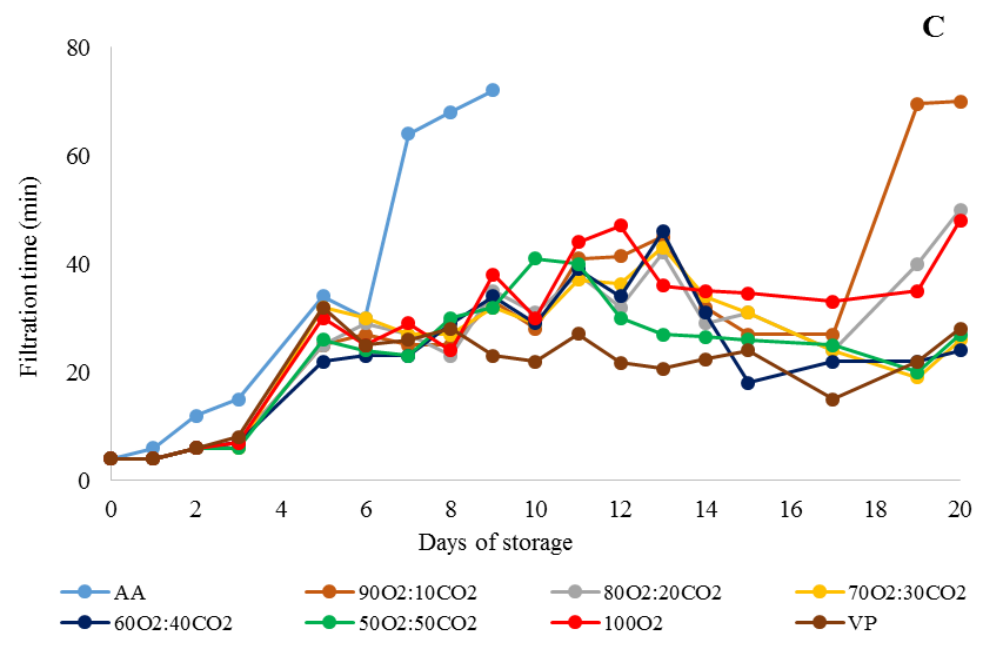

Figure 2. Results of $\mathrm{pH}$ : (A) total volatile basic nitrogen (mg of TVB-N/100 g of meat); (B) and filtration time (min); (C) of the ground beef treated with different packaging systems stored at $2{ }^{\circ} \mathrm{C}$ for 20 days. AA (ambient air); $90 \mathrm{O}_{2}: 10 \mathrm{CO}_{2}, 80 \mathrm{O}_{2}: 20 \mathrm{CO}_{2}, 70 \mathrm{O}_{2}: 30 \mathrm{CO}_{2}, 60 \mathrm{O}_{2}: 40 \mathrm{CO}_{2}, 50 \mathrm{O}_{2}: 50 \mathrm{CO}_{2}$, and $100 \mathrm{O}_{2}$ (modified atmosphere packaging with $90 \%: 10 \%, 80 \%: 20 \%, 70 \%: 30 \%, 60 \%: 40 \%, 50 \%: 50 \%$, and $100 \%: 0 \%$ of oxygen and dioxide carbon ratios, respectively); VP (vacuum packaging). 
The filtration time provides an indirect indication of the water retention capacity of the meat sample, which is also related to the structural integrity of the myofibrils of the ground beef [39]. The proteolytic action of endogenous proteases is responsible for the disorganization of proteins and connective tissue in ground beef. Therefore, in general, a high filtration time indicates a high water holding capacity, which is an indication of protein denaturation and supports the proteolysis of myofibrillar proteins. Changes in the intracellular architecture of fibrils can be induced by autolytic action and can influence the ability of proteins to retain water $[40,41]$. Degradation of these proteins allows water to remain in the cell for a more extended period. This tenderization is an enzymatic alteration; thus, physiochemical conditions may modify the proteolytic activity of endogenous enzymes [42]. These results demonstrate that the effects of different atmosphere systems (several $\mathrm{O}_{2}$ and $\mathrm{CO}_{2}$ ratios and vacuum packaging) might be responsible for the modulation of $\mathrm{pH}$ (Table 1), thereby slowing down the proteolysis and disorganization of the myofibrillar structure, confirmed by the filtration test results [43].

\subsection{Bacterial Growth}

The bacterial growth curves and growth parameters (Lag, GT, and NC) are shown in Figure 3 and Table 2, respectively. The initial count of AMHB was $6.5 \mathrm{Log} \mathrm{cfu} / \mathrm{g}$ of ground beef (Figure 3A). This initially high bacterial count might be due to the inadequate handling of meat samples during slaughtering, cutting, and processing [38]. Moreover, ground beef has a high exposed surface, which results in higher microbial contamination than the surface of whole meat [44].

The AMHB (Figure 3A) and APHB (Figure 3B) counts of the ground beef increased with storage time in all treatments. To determine the shelf life of stored ground beef, we adopted a maximum value of 7.0 Log cfu/g for mesophilic bacterial counts (established by the ICMSF [45]) as a microbiological standard for meat products safe for consumption.

The counts of AMHB in AA grew much faster than those of the other groups, reaching the standard shelf life threshold (7.0 Log cfu/g) [45] on the 3rd day of refrigerated storage (Figure 3A; Table 2). In relation to all other treatments, the AMHB count of $7.0 \mathrm{Log} \mathrm{cfu} / \mathrm{g}$ was achieved on days 6 $\left(90 \mathrm{O}_{2}: 10 \mathrm{CO}_{2}\right), 7\left(70 \mathrm{O}_{2}: 30 \mathrm{CO}_{2}\right.$ and $\left.100 \mathrm{O}_{2}\right)$, and $8\left(80 \mathrm{O}_{2}: 20 \mathrm{CO}_{2}, 60 \mathrm{O}_{2}: 40 \mathrm{CO}_{2}, 50 \mathrm{O}_{2}: 50 \mathrm{CO}_{2}\right.$ and $\left.\mathrm{VP}\right)$. These results may be explained by the effect of the different packaging systems on the bacterial growth parameters. According to Baranyi and Roberts [17], the lag phase is calculated as the time necessary during which bacterial cells modify themselves in order to initiate exponential growth. The generation time is calculated during the exponential phase of growth as the time need for bacterial count to double through growth rate $(\mu \max )$ by the formula GT $=\log (2) / \mu$ max. The stationary phase is calculated as the highest final bacterial count during storage.

AA had the lowest lag phase and generation time (GT; $p<0.05)$, resulting in a shorter shelf life. Although $90 \mathrm{O}_{2}: 10 \mathrm{CO}_{2}$ and $70 \mathrm{O}_{2}: 30 \mathrm{CO}_{2}$ showed a higher GT, they demonstrated a lower lag phase compared to $80 \mathrm{O}_{2}: 20 \mathrm{CO}_{2}, 60 \mathrm{O}_{2}: 40 \mathrm{CO}_{2}$, and $50 \mathrm{O}_{2}: 50 \mathrm{CO}_{2}(p<0.05)$, indicating that the mesophilic bacteria group grew more slowly but adapted more quickly in $90 \mathrm{O}_{2}: 10 \mathrm{CO}_{2}$ and $70 \mathrm{O}_{2}: 30 \mathrm{CO}_{2} \cdot 100 \mathrm{O}_{2}$ and $60 \mathrm{O}_{2}: 40 \mathrm{CO}_{2}$ had similar GT values $(p>0.05)$. However, $60 \mathrm{O}_{2}: 40 \mathrm{CO}_{2}$ demonstrated a higher lag phase than $100 \mathrm{O}_{2}(p<0.05)$. In addition, although VP exhibited a similar $\mathrm{GT}$ to $70 \mathrm{O}_{2}: 30 \mathrm{CO}_{2}$, its lag phase was as long as $60 \mathrm{O}_{2}: 40 \mathrm{CO}_{2}(p>0.05)$.

Likewise, $80 \mathrm{O}_{2}: 20 \mathrm{CO}_{2}, 60 \mathrm{O}_{2}: 40 \mathrm{CO}_{2}, 50 \mathrm{O}_{2}: 50 \mathrm{CO}_{2}, 100 \mathrm{O}_{2}$, and $\mathrm{VP}$ also had higher lag phases or GTs for their APHB counts. $80 \mathrm{O}_{2}: 20 \mathrm{CO}_{2}$ and $50 \mathrm{O}_{2}: 50 \mathrm{CO}_{2}$ showed higher lag phases than $90 \mathrm{O}_{2}: 10 \mathrm{CO}_{2}$ $(p<0.05)$. VP had the highest GT, followed by $100 \mathrm{O}_{2}, 60 \mathrm{O}_{2}: 40 \mathrm{CO}_{2}, 80 \mathrm{O}_{2}: 20 \mathrm{CO}_{2}$, and $50 \mathrm{O}_{2}: 50 \mathrm{CO}_{2}$ $(p<0.05)$. Although $50 \mathrm{O}_{2}: 50 \mathrm{CO}_{2}$ showed a similar GT to $90 \mathrm{O}_{2}: 10 \mathrm{CO}_{2}, 50 \mathrm{O}_{2}: 50 \mathrm{CO}_{2}$ had the highest lag phase among all treatments $(p<0.05) .80 \mathrm{O}_{2}: 20 \mathrm{CO}_{2}$ and VP had a higher lag phase than $90 \mathrm{O}_{2}: 10 \mathrm{CO}_{2}$ and $100 \mathrm{O}_{2}(p<0.05)$. Furthermore, $70 \mathrm{O}_{2}: 30 \mathrm{CO}_{2}$ demonstrated a higher lag phase than all other treatments, except for $50 \mathrm{O}_{2}: 50 \mathrm{CO}_{2}$. However, $70 \mathrm{O}_{2}: 30 \mathrm{CO}_{2}$ had the lowest GT among the MAP treatments $(p<0.05)$. Furthermore, the highest viable cells in the stationary phase (NC) were found in $60 \mathrm{O}_{2}: 40 \mathrm{CO}_{2}$ and $50 \mathrm{O}_{2}: 50 \mathrm{CO}_{2}$ for both the AMHB and APHB groups $(p<0.05)$. This fact may be attributed to the sublethal injury to bacterial cells induced by different $\mathrm{O}_{2}$ and $\mathrm{CO}_{2}$ ratios, leading to injured cells 
initially growing slower than intact cells, followed by the rapid growth of recovered cells, mainly in a medium without natural competition [46,47].

A
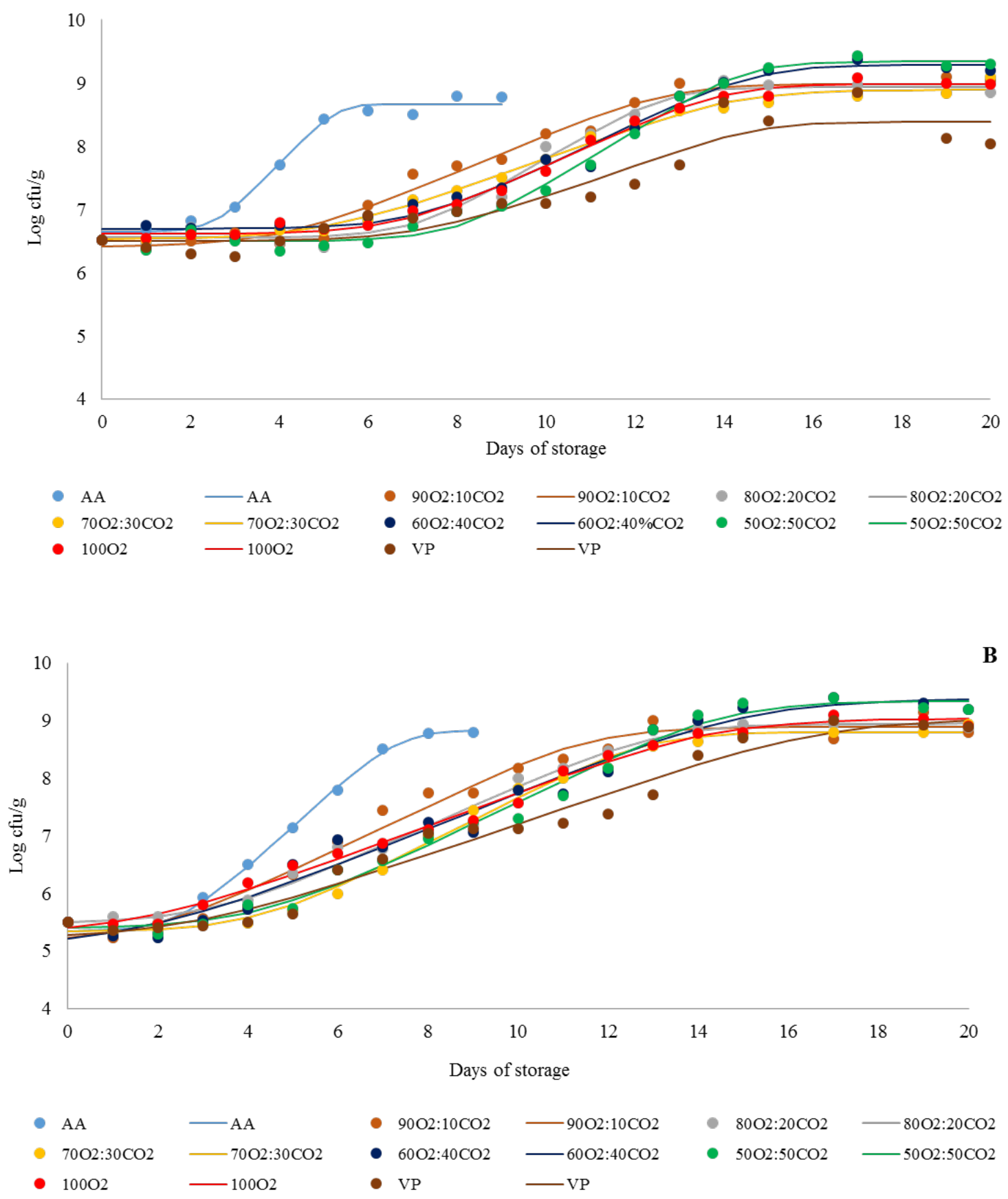

Figure 3. Growth curve of aerobic mesophilic heterotrophic bacteria (A) and aerobic psychrotrophic heterotrophic bacteria (B) of ground beef treated with different packaging systems stored at $2{ }^{\circ} \mathrm{C}$ for 20 days. AA (ambient air); $90 \mathrm{O}_{2}: 10 \mathrm{CO}_{2}, 80 \mathrm{O}_{2}: 20 \mathrm{CO}_{2}, 70 \mathrm{O}_{2}: 30 \mathrm{CO}_{2}, 60 \mathrm{O}_{2}: 40 \mathrm{CO}_{2}, 50 \mathrm{O}_{2}: 50 \mathrm{CO}_{2}$, and $100 \mathrm{O}_{2}$ (modified atmosphere packaging with $90 \%: 10 \%, 80 \%: 20 \%, 70 \%: 30 \%, 60 \%: 40 \%, 50 \%: 50 \%$, and 100\%:0\% oxygen and dioxide carbon ratios, respectively); VP (vacuum packaging). Log cfu/g-Log colony forming units per gram. Filled circles indicate the real average values $(n=2)$, and lines represent the values fitted by the predictive primary model designed by Baranyi and Roberts [17]. 
Table 2. Bacterial growth parameters of ground beef treated with different packaging systems stored at $2{ }^{\circ} \mathrm{C}$ for 20 days.

\begin{tabular}{|c|c|c|c|c|}
\hline Treatments $€$ & Parameters $^{£}$ & АМНB $\psi$ & АРНB $\psi$ & Shelf Life * (Days) \\
\hline \multirow{3}{*}{ AA } & Lag & $2.53 \pm 0.02 \mathrm{~g}$ & $2.45 \pm 0.00^{\mathrm{e}}$ & \multirow{3}{*}{3} \\
\hline & GT & $0.95 \pm 0.01^{\mathrm{e}}$ & $0.97 \pm 0.00 \mathrm{~g}$ & \\
\hline & NC & $8.67 \pm 0.00 \mathrm{~g}$ & $8.84 \pm 0.00 \mathrm{~g}$ & \\
\hline \multirow{3}{*}{$90 \mathrm{O}_{2}: 10 \mathrm{CO}_{2}$} & Lag & $4.04 \pm 0.01^{\mathrm{f}}$ & $1.98 \pm 0.01^{f}$ & \multirow{3}{*}{6} \\
\hline & GT & $2.35 \pm 0.01^{b}$ & $1.82 \pm 0.00^{\mathrm{e}}$ & \\
\hline & $\mathrm{NC}$ & $8.99 \pm 0.00^{\mathrm{d}}$ & $8.89 \pm 0.00^{f}$ & \\
\hline \multirow{3}{*}{$80 \mathrm{O}_{2}: 20 \mathrm{CO}_{2}$} & Lag & $6.96 \pm 0.03^{c}$ & $3.20 \pm 0.00^{c}$ & \multirow{3}{*}{8} \\
\hline & GT & $1.70 \pm 0.01^{\mathrm{d}}$ & $1.99 \pm 0.00^{\mathrm{d}}$ & \\
\hline & $\mathrm{NC}$ & $8.94 \pm 0.00^{\mathrm{e}}$ & $8.95 \pm 0.00^{\mathrm{e}}$ & \\
\hline \multirow{3}{*}{$70 \mathrm{O}_{2}: 30 \mathrm{CO}_{2}$} & Lag & $4.97 \pm 0.03^{\mathrm{e}}$ & $4.20 \pm 0.01^{b}$ & \multirow{3}{*}{7} \\
\hline & GT & $2.76 \pm 0.02^{\mathrm{a}}$ & $1.72 \pm 0.00^{f}$ & \\
\hline & $\mathrm{NC}$ & $8.89 \pm 0.00^{f}$ & $8.80 \pm 0.00^{h}$ & \\
\hline \multirow{3}{*}{$60 \mathrm{O}_{2}: 40 \mathrm{CO}_{2}$} & Lag & $7.04 \pm 0.03^{b, c}$ & $1.96 \pm 0.00^{f}$ & \multirow{3}{*}{8} \\
\hline & GT & $2.07 \pm 0.02^{\mathrm{c}}$ & $2.20 \pm 0.00^{\mathrm{c}}$ & \\
\hline & NC & $9.29 \pm 0.00^{b}$ & $9.37 \pm 0.00^{a}$ & \\
\hline \multirow{3}{*}{$50 \mathrm{O}_{2}: 50 \mathrm{CO}_{2}$} & Lag & $7.99 \pm 0.03^{a}$ & $4.26 \pm 0.01^{\mathrm{a}}$ & \multirow{3}{*}{8} \\
\hline & GT & $1.59 \pm 0.01^{\mathrm{d}}$ & $1.82 \pm 0.00^{\mathrm{e}}$ & \\
\hline & $\mathrm{NC}$ & $9.34 \pm 0.01^{\mathrm{a}}$ & $9.34 \pm 0.00^{b}$ & \\
\hline \multirow{3}{*}{$100 \mathrm{O}_{2}$} & Lag & $6.63 \pm 0.02^{d}$ & $1.96 \pm 0.00^{f}$ & \multirow{3}{*}{7} \\
\hline & GT & $2.18 \pm 0.01^{\mathrm{c}}$ & $2.37 \pm 0.00^{b}$ & \\
\hline & NC & $8.99 \pm 0.00^{c}$ & $9.03 \pm 0.00^{d}$ & \\
\hline \multirow{3}{*}{ VP } & Lag & $7.20 \pm 0.14^{b}$ & $2.84 \pm 0.00^{d}$ & \multirow{3}{*}{8} \\
\hline & GT & $2.80 \pm 0.08^{a}$ & $2.57 \pm 0.00^{\mathrm{a}}$ & \\
\hline & $\mathrm{NC}$ & $8.39 \pm 0.00^{h}$ & $9.03 \pm 0.00^{c}$ & \\
\hline
\end{tabular}

Results are expressed as the means \pm standard deviation $(n=2){ }^{\text {a-h }}$ Different letters in the same column indicate, within the same parameter, significant differences $(p<0.05)$ between treatments. ${ }^{€} \mathrm{AA}$ (ambient air); $90 \mathrm{O}_{2}: 10 \mathrm{CO}_{2}$, $80 \mathrm{O}_{2}: 20 \mathrm{CO}_{2}, 70 \mathrm{O}_{2}: 30 \mathrm{CO}_{2}, 60 \mathrm{O}_{2}: 40 \mathrm{CO}_{2}, 50 \mathrm{O}_{2}: 50 \mathrm{CO}_{2}$, and $100 \mathrm{O}_{2}$ (modified atmosphere packaging with $90 \%: 10 \%$, $80 \%: 20 \%, 70 \%: 30 \%, 60 \%: 40 \%, 50 \%: 50 \%$, and $100 \%: 0 \%$ of oxygen and dioxide carbon ratios, respectively); VP (vacuum packaging). ${ }^{£}$ Lag-lag phase (h); GT-generation time (h); NC—number of colonies in the stationary phase (Log $\mathrm{cfu} / \mathrm{g})$. $\Psi$ AMHB-aerobic mesophilic heterotrophic bacteria; APHB - aerobic psychrotrophic heterotrophic bacteria. * The time necessary for average AMHB count values to attain a threshold of $7.0 \mathrm{Log} \mathrm{cfu} / \mathrm{g} \mathrm{[45]} \mathrm{over} \mathrm{the} \mathrm{entire}$ storage period of 20 days at $4{ }^{\circ} \mathrm{C}$.

According to our results, the $\mathrm{O}_{2} / \mathrm{CO}_{2}-\mathrm{MAP}$ is proven to have an antibacterial effect $[23,48,49]$. The high solubility of $\mathrm{CO}_{2}$ in water and fat leads to the formation of carbonic acid and a reduction in meat $\mathrm{pH}$, resulting in an unfavorable acidic environment for bacterial growth $[31,50]$. The use of $\mathrm{O}_{2}$ is necessary in beef to maintain its attractive red color [1], and, despite the direct bacteriostatic effect from $\mathrm{CO}_{2}, \mathrm{O}_{2}$ influences the growth of different bacterial groups depending on its levels [34,35]. Therefore, different $\mathrm{CO}_{2}$ and $\mathrm{O}_{2}$ ratios result in changes in microbial metabolism and subsequent differences in the partial pressure of gases, which is directly related to gas solubility and is a key factor in the antimicrobial effectiveness of MAP systems. Furthermore, the effect of different $\mathrm{CO}_{2}$ and $\mathrm{O}_{2}$ ratios also depends on the intrinsic chemical characteristics of the meat cut, such as its proximate composition [15,16]. According to Hunt et al. [51], Serratus ventralis muscles contain $9.84 \%$ lipids, $20.52 \%$ proteins, and $67.61 \%$ moisture. In this way, the largest challenge to the successful application of MAP is to find the optimal gas composition for each food product since MAP systems with higher $\mathrm{CO}_{2}$ levels are not necessarily the most effective ones and are mainly used for food with a high surface area, such as ground beef. Therefore, studies focusing in the knowledge about the effects of MAP with different gas ratios in beef muscle, which are widely used to make ground beef but not studied yet, as the present study, contribute strongly to industrial MAP application. In partial agreement with our 
findings, Yang et al. [52] reported similar effects in two MAP systems $\left(80 \% \mathrm{O}_{2}+20 \% \mathrm{CO}_{2}\right.$ and $50 \% \mathrm{O}_{2}$ $+30 \% \mathrm{CO}_{2}+20 \% \mathrm{~N}_{2}$ ) against bacterial growth in beef steaks during 12 days of refrigerated storage.

VP demonstrated results comparable to some $\mathrm{O}_{2} / \mathrm{CO}_{2}-\mathrm{MAP}$ systems, which may be explained by the removal of oxygen, which inhibits the growth of obligate aerobic bacteria $[34,35]$. These results corroborate those of previous studies that demonstrated an equal or better bacterial quality of meat under vacuum conditions compared to MAP containing different levels of $\mathrm{O}_{2}$ and $\mathrm{CO}_{2}[52,53]$. The growth of aerobic bacteria in VP samples may be attributed to the growth of acid lactic bacteria, which grows in the absence or presence of $\mathrm{O}_{2}$, mainly in environments without natural competition [32,33]. Moreover, vacuum packaging retains approximately $5 \%$ residual oxygen due to the inability to completely remove $\mathrm{O}_{2}$ and the penetration of $\mathrm{O}_{2}$ through the packaging during the storage period [54,55]. Nevertheless, vacuum packaging cause changes to the meat color (creating a purple color), which is undesirable to consumers [56]. On the other hand, $\mathrm{O}_{2}$ may induce lipid oxidation, one of the main non-microbiological factors leading to meat deterioration during refrigerated storage. This phenomenon causes a loss of nutrients, off-flavor, discoloration, limited shelf life, and the formation of compounds harmful to human health $[7,57]$. Therefore, further studies are necessary to evaluate the oxidative stability of ground beef submitted to MAP $50-80 \% \mathrm{O}_{2}$ levels and VP throughout refrigerated storage.

The results found for $100 \mathrm{O}_{2}$ may be attributed to the high concentrations of $\mathrm{O}_{2}$ due to the required $\mathrm{O}_{2}$ levels (around 21\%) for optimal bacterial growth [58]. The toxicity of high $\mathrm{O}_{2}$ to aerobic bacteria may be associated with the formation of superoxide radicals $\left(\mathrm{O}_{2}{ }^{-}\right)[59]$.

\section{Conclusions}

All MAP packaging systems equally delay the loss of physicochemical quality during refrigerated storage of ground beef. However, the predictive microbiological parameters revealed that the most effective MAP systems were $80 \mathrm{O}_{2}: 20 \mathrm{CO}_{2}, 60 \mathrm{O}_{2}: 40 \mathrm{CO}_{2}, 50 \mathrm{O}_{2}: 50 \mathrm{CO}_{2}$, and $\mathrm{VP}$, which extended the shelf life of the ground beef by five days, while $90 \mathrm{O}_{2}: 10 \mathrm{CO}_{2}, 70 \mathrm{O}_{2}: 30 \mathrm{CO}_{2}$, and $100 \mathrm{O}_{2}$ extended the shelf life by 3,4 , and 4 days, respectively. VP was as effective as $80 \mathrm{O}_{2}: 20 \mathrm{CO}_{2}, 60 \mathrm{O}_{2}: 40 \mathrm{CO}_{2}$, and $50 \mathrm{O}_{2}: 50 \mathrm{CO}_{2}$. However, VP is known to change the color of fresh beef, which is an essential attribute for consumer acceptance of red meat products. Therefore, $80 \mathrm{O}_{2}: 20 \mathrm{CO}_{2}, 60 \mathrm{O}_{2}: 40 \mathrm{CO}_{2}$, and $50 \mathrm{O}_{2}: 50 \mathrm{CO}_{2}$ offer a simple and effective method to preserve the physicochemical quality and enhance the shelf life of ground beef stored at $2{ }^{\circ} \mathrm{C}$ for 20 days. Further studies should be performed to evaluate the oxidative potential of MAP with $50-80 \% \mathrm{O}_{2}$ levels for minced meat.

Author Contributions: Conceptualization, C.A.C.-J., E.T.M., and S.B.M.; Study Execution and Methodology, C.A.C.-J., R.P., M.M.L., and T.S.A.; Data Curation and Statistical Analysis, C.A.C.-J., M.L.G.M., and S.B.M.; Writing-Original Draft Preparation, C.A.C.-J. and M.L.G.M.; Writing-Review and Editing, C.A.C.-J., M.L.G.M. and S.B.M.; Supervision and Project Administration, C.A.C.-J. and S.B.M.; Funding Acquisition, C.A.C.-J. All authors have read and agreed to the published version of the manuscript.

Funding: The authors are thankful for the financial support provided by the Fundação de Amparo à Pesquisa do Estado do Rio de Janeiro (Grant No. E-26/203.049/2017); Coordenação de Aperfeiçoamento de Pessoal de Nível Superior (Grant Nos. 125, CAPES/Embrapa 2014, E-26/201.825/2017, CAPES/FAPERJ E-45-PAPDRJ/2013, E-26/202.136/2018, and Finance Code 001); and Conselho Nacional de Desenvolvimento Científico e Tecnológico (Grant No. 311422/2016).

Conflicts of Interest: The authors declare no conflict of interest.

\section{References}

1. Santos, P.R.; Donado-Pestana, C.M.; Delgado, E.F.; Tanaka, F.O.; Contreras-Castillo, C.J. Tenderness and oxidative stability of Nellore bulls steaks packaged under vacuum or modified atmosphere during storage at 2 C. Food Packag. Shelf Life 2015, 4, 10-18. [CrossRef]

2. Smaoui, S.; Hsouna, A.B.; Lahmar, A.; Ennouri, K.; Mtibaa-Chakchouk, A.; Sellem, I.; Najah, S.; Bouaziz, M.; Mellouli, L. Bio-preservative effect of the essential oil of the endemic Mentha piperita used alone and in combination with BacTN635 in stored minced beef meat. Meat Sci. 2016, 117, 196-204. [CrossRef] [PubMed] 
3. Salim, A.P.A.; Canto, A.C.; Costa-Lima, B.R.; Simoes, J.S.; Panzenhagen, P.H.; Costa, M.P.; Franco, R.M.; Silva, T.J.P.; Conte-Junior, C.A. Inhibitory effect of acid concentration, aging, and different packaging on Escherichia coli O157: H7 and on color stability of beef. J. Food Process. Preserv. 2018, 42, e13402. [CrossRef]

4. Vaclavik, V.A.; Christian, E.W. Essentials of Food Science, 4th ed.; Springer: New York, NY, USA, 2014; pp. 323-342.

5. Rodrigues, B.L.; da Silveira Alvares, T.; Sampaio, G.S.L.; Cabral, C.C.; Araujo, J.V.A.; Franco, R.M.; Mano, S.B.; Conte-Junior, C.A. Influence of vacuum and modified atmosphere packaging in combination with UV-C radiation on the shelf life of rainbow trout (Oncorhynchus mykiss) fillets. Food Control 2016, 60, 596-605. [CrossRef]

6. Rodriguez, M.; Conte-Junior, C.; Carneiro, C.; Lázaro, C.; Mano, S. Biogenic amines as a quality index in shredded cooked chicken breast fillet stored under refrigeration and modified atmosphere. J. Food Process. Preserv. 2015, 39, 2043-2048. [CrossRef]

7. Lund, M.N.; Lametsch, R.; Hviid, M.S.; Jensen, O.N.; Skibsted, L.H. High-oxygen packaging atmosphere influences protein oxidation and tenderness of porcine longissimus dorsi during chill storage. Meat Sci. 2007, 77, 295-303. [CrossRef]

8. Canto, A.C.; Costa-Lima, B.R.; Suman, S.P.; Monteiro, M.L.G.; Viana, F.M.; Salim, A.P.A.; Nair, M.N.; Silva, T.J.P.; Conte-Junior, C.A. Color attributes and oxidative stability of longissimus lumborum and psoas major muscles from Nellore bulls. Meat Sci. 2016, 121, 19-26. [CrossRef]

9. Soladoye, O.; Juárez, M.; Aalhus, J.; Shand, P.; Estévez, M. Protein oxidation in processed meat: Mechanisms and potential implications on human health. Compr. Rev. Food Sci. Food Saf. 2015, 14, 106-122. [CrossRef]

10. Łopacka, J.; Półtorak, A.; Wierzbicka, A. Effect of MAP, vacuum skin-pack and combined packaging methods on physicochemical properties of beef steaks stored up to 12 days. Meat Sci. 2016, 119, 147-153. [CrossRef]

11. Łopacka, J.; Półtorak, A.; Wierzbicka, A. Effect of reduction of oxygen concentration in modified atmosphere packaging on bovine M. longissimus lumborum and M. gluteus medius quality traits. Meat Sci. 2017, 124, 1-8. [CrossRef]

12. Lu, X.; Cornforth, D.P.; Carpenter, C.E.; Luo, L.Z.X. Effect of oxygen concentration in modified atmosphere packaging on color changes of the M. longissimus thoraces et lumborum from dark cutting beef carcasses. Meat Sci. 2020, 161, 107999. [CrossRef] [PubMed]

13. Esmer, O.K.; Irkin, R.; Degirmencioglu, N.; Degirmencioglu, A. The effects of modified atmosphere gas composition on microbiological criteria, color and oxidation values of minced beef meat. Meat Sci. 2011, 88, 221-226. [CrossRef] [PubMed]

14. Wang, H.; Luo, Y.; Ertbjerg, P. Myofibrillar protein gel properties are influenced by oxygen concentration in modified atmosphere packaged minced beef. Food Chem. 2017, 230, 475-481. [CrossRef] [PubMed]

15. Farber, J.M. Microbiological aspects of modified-atmosphere packaging technology: A review. J. Food Prot. 1991, 54, 58-70. [CrossRef] [PubMed]

16. Singh, P.; Wani, A.A.; Saengerlaub, S.; Langowski, H. Understanding critical factors for the quality and shelf-life of MAP fresh meat: A Review. Crit. Rev. Food Sci. Nutr. 2011, 51, 146-177. [CrossRef]

17. Baranyi, J.; Roberts, T.A. A dynamic approach to predicting bacterial growth in food. Int. J. Food Microbiol. 1994, 23, 277-294. [CrossRef]

18. Conte-Junior, C.A.; de Souza, V.G.; Batista, R.F.; Mársico, E.T.; Mano, S.B. Influência do ácido lático e da embalagem em atmosfera modificada sobre a validade comercial da linguiça frescal de frango. Rev. Bras. Ciênc. Vet. 2010, 17, 59-66.

19. Association of Official Analytical Chemists. Official Methods of Analysis of AOAC, 17th ed.; AOAC: Gaithersburg, MD, USA, 2000.

20. BRAZIL; Ministério da Agricultura, Pecuária e Abastecimento (MAPA). Secretaria Nacional de Defesa Agropecuária. Laboratório Nacional de Referência Animal (LANARA). Portaria n 01 de 07 de outubro de 1981. Métodos Analíticos Oficiais para Controle de Produtos de Origem Animal e seus Ingredientes: Métodos Físicos e Químicos. Diário Oficial da União: Brasília, DF, 1981. Available online: http:// sistemasweb.agricultura.gov.br/sislegis/action/detalhaAto.do?method=consultarLegislacaoFederal (accessed on 13 April 2020).

21. Popa, V.I.; Tanase, E.; Geicu-Cristea, M.; Nicolae, C.; Gabor, R.A. Some important quality parameters of pork meat-biodegradable pack system monitoring at refrigeration storage. Sci. Bull. Ser. F Biotechnol. 2013, XVII, 110-116. 
22. American Public Health Association. Compendium of Methods for the Microbiological Examination of Foods, 4th ed.; APHA: Washington, DC, USA, 2001.

23. Rouger, A.; Moriceau, N.; Prévost, H.; Remenant, B.; Zagorec, M. Diversity of bacterial communities in French chicken cuts stored under modified atmosphere packaging. Food Microbiol. 2018, 70, 7-16. [CrossRef]

24. Guillard, V.; Couvert, O.; Stahl, V.; Hanin, A.; Denis, C.; Huchet, V.; Chaix, E.; Loriot, C.; Vincelot, T.; Thuault, D. Validation of a predictive model coupling gas transfer and microbialgrowth in fresh food packed under modified atmosphere. Food Microbiol. 2016, 58, 43-55. [CrossRef]

25. Zakrys-Waliwander, P.; O'Sullivan, M.; Walsh, H.; Allen, P.; Kerry, J. Sensory comparison of commercial low and high oxygen modified atmosphere packed sirloin beef steaks. Meat Sci. 2011, 88, 198-202. [CrossRef] [PubMed]

26. Ercolini, D.; Russo, F.; Torrieri, E.; Masi, P.; Villani, F. Changes in the spoilage-related microbiota of beef during refrigerated storage under different packaging conditions. Appl. Environ. Microbiol. 2006, 72, 4663-4671. [CrossRef] [PubMed]

27. Tofteskov, J. Mathematical Modelling of Modified Atmosphere Packagings Effect on the Shelf Life of Fresh Meat. Ph.D. Thesis, Roskilde University, Roskilde, Denmark, 2018.

28. Zhang, M.; Meng, X.; Bhandari, B.; Fang, Z.; Chen, H. Recent application of modified atmosphere packaging (MAP) in fresh and fresh-cut foods. Food Rev. Int. 2015, 31, 172-193. [CrossRef]

29. BRAZIL; Ministério da Agricultura, Pecuária e Abastecimento (MAPA). Decreto nº 9.013 de 29 de março de 2017. Regulamento da Inspeção Industrial e Sanitária de Produtos de Origem Animal (RIISPOA). Diário Oficial da União: Brasília, DF, 2017. Available online: http://sistemasweb.agricultura.gov.br/sislegis/action/ detalhaAto.do?method =consultarLegislacaoFederal (accessed on 13 April 2020).

30. Simoes, J.S.; Mársico, E.T.; Lázaro, C.A.; Ferreira, M.S.; Franco, R.M.; Pereira, A.P.; Conte-Junior, C.A. Microbiological, physical and chemical characteristics of freshwater prawns (Macrobrachium rosenbergii) in modified-atmosphere packaging. Int. J. Food Sci. Tech. 2015, 50, 128-135. [CrossRef]

31. Conte-Júnior, C.A.; Fernández, M.; Mano, S. Use of carbon dioxide to control the microbial spoilage of bullfrog (Rana catesbeiana) meat. In Modern Multidisciplinary Applied Microbiology: Exploiting Microbes and Their Interactions, 1st ed.; Mendez-Vilas, A., Ed.; Wiley: Weinheim, Germany, 2006; pp. 356-361.

32. Gram, L.; Huss, H.H. Microbiological spoilage of fish and fish products. Int. J. Food Microbiol. 1996, 33, 121-137. [CrossRef]

33. Stahlke, E.R.; Rossa, L.S.; Silva, G.M.; Sotomaior, C.S.; Pereira, A.J.; Luciano, F.B.; Borges, T.D.; Macedo, R.E.F. Effects of modified atmosphere packaging (MAP) and slaughter age on the shelf life of lamb meat. Food Sci. Technol. 2019, 39, 328-335. [CrossRef]

34. Blacha, I.; Krischek, C.; Klein, G. Quality alterations of turkey and pig meat during storage in modified atmosphere or vacuum packages. J. Food Saf. Food Q. 2013, 64, 160-167.

35. Kernberger-Fischer, I.; Kehrenberg, C.; Klein, G.; Schaudien, D.; Krischek, C. Influence of modified atmosphere and vacuum packaging with and without nanosilver-coated films on different quality parameters of pork. J. Food Sci. Technol. 2017, 54, 3251-3259. [CrossRef]

36. Monteiro, M.L.G.; Mársico, E.T.; Mano, S.B.; Teixeira, C.E.; Canto, A.C.V.C.; de Carvalho Vital, H.; Conte-Júnior, C.A. Influence of good manufacturing practices on the shelf life of refrigerated fillets of tilapia (Oreochromis niloticus) packed in modified atmosphere and gamma-irradiated. Food Sci. Nutr. 2013, 1, 298-306. [CrossRef]

37. Rodrigues, B.L.; dos Santos, L.R.; Mársico, E.T.; Camarinha, C.C.; Mano, S.B.; Junior, C.A.C. Qualidade físico-química do pescado utilizado na elaboração de sushis e sashimis de atum e salmão comercializados no município do Rio de Janeiro, Brasil. Semina Ciênc. Agrár. 2012, 33, 1847-1854. [CrossRef]

38. Kachele, R.; Zhang, M.; Gao, Z.; Adhikari, B. Effect of vacuum packaging on the shelf-life of silver carp (Hypophthalmichthys molitrix) fillets stored at $4{ }^{\circ} \mathrm{C}$. LWT Food Sci. Technol. 2017, 80, 163-168. [CrossRef]

39. De Palo, P.; Maggiolino, A.; Centoducati, P.; Tateo, A. Effects of two different packaging materials on veal calf meat quality and shelf life. J. Anim. Sci. 2013, 91, 2920-2930. [CrossRef] [PubMed]

40. Costa-Lima, B.R.; Canto, A.C.; Suman, S.P.; Conte-Junior, C.A.; Silveira, E.T.; Silva, T.J. Sex-specific effect of ractopamine on quality attributes of pork frankfurters. Meat Sci. 2014, 96, 799-805. [CrossRef] [PubMed]

41. Guimaraes, C.; Marsico, E.; Lazaro, C.; Assis, M.; Guimaraes, A.; Hofmeister, A.; Mano, S.; Conte-Junior, C. Effect of the anatomical point of hanging and dripping time on water retention of chicken carcasses. J. Appl. Poult. Res. 2015, 25, 80-84. [CrossRef] 
42. Delbarre-Ladrat, C.; Chéret, R.; Taylor, R.; Verrez-Bagnis, V. Trends in postmortem aging in fish: Understanding of proteolysis and disorganization of the myofibrillar structure. Crit. Rev. Food Sci. Nutr. 2006, 46, 409-421. [CrossRef]

43. Murphy, K.; O'Grady, M.; Kerry, J. Effect of varying the gas headspace to meat ratio on the quality and shelf-life of beef steaks packaged in high oxygen modified atmosphere packs. Meat Sci. 2013, 94, 447-454. [CrossRef]

44. Kasnowski, C.M.; Franco, R.M.; Oliveira, L.A.T.; Valente, A.M.; Carvalho, J.C.A.; Conte-Junior, C.A. Detección, caracterización serológica y antibiogramas de Escherichia coli aisladas de carne de ternera (babilla) entera y picada. Rev. Salud Publica Nutr. 2008, 9, 1-10.

45. International Commission on Microbiological Specifications for Foods (ICMSF). Microorganisms in Foods: Application of Hazard Analysis Critical Point (HACCP) System to Ensure Microbiological Safety and Quality, 1st ed.; Blackwell: London, UK, 1988.

46. Li, J.; Kolling, G.L.; Matthews, K.R.; Chikindas, M.L. Cold and carbon dioxide used as multi-hurdle preservation do not induce appearance of viable but non-culturable Listeria monocytogenes. J. Appl. Microbiol. 2003, 94, 48-53. [CrossRef]

47. Izumi, H.; Inoue, A. Viability of sublethally injured coliform bacteria on fresh-cut cabbage stored in high $\mathrm{CO}_{2}$ atmospheres following rinsing with electrolyzed water. Int. J. Food Microbiol. 2018, 266, 207-212. [CrossRef]

48. Daniels, J.A.; Krishnamurthi, R.; Rizvi, S.S.H. A review of effects of carbon dioxide on microbial growth and food quality. J. Food Prot. 1985, 48, 532-537. [CrossRef]

49. Rodriguez, M.; Junior, C.C.; Carneiro, C.; Franco, R.; Mano, S. The effect of carbon dioxide on the shelf life of ready-to-eat shredded chicken breast stored under refrigeration. Poult. Sci. 2013, 93, 194-199. [CrossRef]

50. Alam, T.; Goyal, G.K. Color and pigment changes during modified atmosphere packaging storage of fruits and vegetables. Stewart Postharvest Rev. 2006, 5, 1-9.

51. Hunt, M.R.; Legako, J.F.; Dinh, T.T.N.; Garmyn, A.J.; O’Quinn, T.G.; Corbin, C.H.; Rathmann, R.J.; Brooks, J.C.; Miller, M.F. Assessment of volatile compounds, neutral and polar lipid fatty acids of four beef muscles from USDA Choice and Select graded carcasses and their relationships with consumer palatability scores and intramuscular fat content. Meat Sci. 2016, 116, 91-101. [CrossRef] [PubMed]

52. Yang, X.; Zhang, Y.; Zhu, L.; Han, M.; Gao, S.; Luo, X. Effect of packaging atmospheres on storage quality characteristics of heavily marbled beef longissimus steaks. Meat Sci. 2016, 117, 50-56. [CrossRef] [PubMed]

53. Rogers, H.B.; Brooks, J.C.; Martin, J.N.; Tittor, A.; Miller, M.F.; Brashears, M.M. The impact of packaging system and temperature abuse on the shelf life characteristics of ground beef. Meat Sci. 2014, 97, 1-10. [CrossRef]

54. Prasad, P.; Kochhar, A. Active packaging in food industry. J. Environ. Sci. Toxicol. Food Technol. 2014, 8, 1-7.

55. Goncalves, A.; Mendes, R.; Nunes, M.L. Effect of oxygen absorber on the shelf life of gilthead seabream (Sparus aurata). J. Aquat. Food Prod. Technol. 2004, 13, 49-59. [CrossRef]

56. Lagerstedt, Å.; Ahnström, M.L.; Lundström, K. Vacuum skin pack of beef-A consumer friendly alternative. Meat Sci. 2011, 88, 391-396. [CrossRef]

57. Falowo, A.B.; Fayemi, P.O.; Muchenje, V. Natural antioxidants against lipid-protein oxidative deterioration in meat and meat products: A review. Food Res. Int. 2014, 64, 171-181. [CrossRef]

58. Cunha, F.L.; Monteiro, M.L.G.; Júnior, C.A.C.; de La Torre, C.A.L.; Santos, E.B.; de Carvalho Vital, H.; Mársico, E.T.; Mano, S. Determinação e monitoramento de aminas biogênicas por cromatografia líquida de alta eficiência em filés de tilápia do Nilo (Oreochromis niloticus) resfriados embalados em atmosfera modificada e irradiados. Braz. J. Vet. Med. 2013, 35, 275-282.

59. Zheng, Y.; Yang, Z.; Chen, X. Effect of high oxygen atmospheres on fruit decay and quality in Chinese bayberries, strawberries and blueberries. Food Control 2008, 19, 470-474. [CrossRef]

(C) 2020 by the authors. Licensee MDPI, Basel, Switzerland. This article is an open access article distributed under the terms and conditions of the Creative Commons Attribution (CC BY) license (http://creativecommons.org/licenses/by/4.0/). 